\title{
Dissolved free amino acids in the marine environment: a carbon to nitrogen ratio shift during diatom blooms
}

\author{
K. D. Hammer \& G. Kattner \\ Institut für Biochemie und Lebensmittelchemie der Universität Hamburg, Martin-Luther-King-Platz 6, D-2000 Hamburg 13, \\ Federal Republic of Germany
}

\begin{abstract}
Variations in concentrations of dissolved free amino acids (DFAA) were investigated during a phytoplankton bloom in the northern North Sea (Fladen Ground Area). Carbon to nitrogen ratios $(\mathrm{C} / \mathrm{N})$ were calculated from the distribution patterns of the individual amino acids and related to biological and chemical developments. The ratio shifted from winter conditions of about 2.9 to values of more than 3.6 during the steady state phase and showed significant correlations only with the distribution of diatoms, mainly Chaetoceros species in the euphotic zone. Here phytoflagellates as well as zooplankton showed positive correlations with ornithine and lysine (zooplankton also with aspartic acid). Peridineans were negatively correlated with threonine. During the early exponential diatom growth phase a DFAA maximum occurred with a $\mathrm{C} / \mathrm{N}$ ratio of 3.16 in the water column above the thermocline, while below there was a maximum with a ratio of 3.71 in the late exponential phase. With the help of similar results from an enclosed diatom culture of Thalassiosira rotula an attempt was made to relate the temporal and spatial $\mathrm{C} / \mathrm{N}$ distributions to the physiological state of the diatoms.
\end{abstract}

\section{INTRODUCTION}

In seawater the major fraction of organic matter is the so-called dissolved organic carbon (DOC), showing a typical concentration range from 0.5 to $2.0 \mathrm{mg} \mathrm{C}$ $\mathrm{dm}^{-3}$ (Williams 1975, MacKinnon 1981). Phytoplankton is the main source of DOC, which is released via exudation from living organisms or during decomposition processes on dead material (Williams 1975, Fogg 1977, Bada \& Lee 1977, Wangersky 1978). In marine ecosystems the different compounds of the wide DOC spectrum may perform various functions in, for example, heterotrophic nutrition, metal complexation and growth control. However, in trying to understand the relations between these substances and the plankton community it is necessary to investigate the fate of single bioactive compounds at their natural concentration levels, which generally lie several orders of magnitude below those of bulk parameters like DOC (Dawson \& Duursma 1981).

The nature and interactions of nitrogen-containing compounds in DOC are complicated and, up to now, only partly understood. Though dissolved free amino acids (DFAA) comprise a small fraction of DOC, these substances are subject to high fluxes with turnover times in the range of 1 to $100 \mathrm{~h}$ (Crawford et al. 1974, Hollibaugh 1980). In marine environments DFAA concentrations are mostly in a well-balanced steady state between the various release and uptake processes. Biological events, such as phytoplankton blooms, can disturb the steady state over a short time period. The resulting shifts in concentration and distribution patterns of the individual substances may then reflect biological interactions.

There is a confusing amount of data concerning changes in DFAA during biological events. The spectrum of results is widely extended from no interrelations with phytoplankton (Macko et al. 1982, Williams \& Poulet 1986) to accumulations of single amino acids at density gradient boundaries (Liebezeit et al. 1980, Poulet et al. 1984) and diel variations in distribution patterns (Mopper \& Lindroth 1982). More or less fixed patterns of DFAA during phytoplankton development were reported by Laanbroek et al. (1985). Significant correlations of individual DFAA with the physiological state of the algae were reported for an enclosed diatom bloom (Hammer \& Brockmann 1983). Benthic diatom species were shown in vitro to take up DFAA in a 
nitrate-poor medium (Admiraal et al. 1984). Depletion of nitrogen and carbon increased uptake of DFAA (Wheeler et al. 1974, Fynn \& Syrett 1985). Phytoplankton contains 1 to $3 \%$ nitrogen (dry weight), mainly fixed in intracellular DFAA pools $(15$ to $20 \%)$ and protein (70 to $90 \%$ ). During nitrogen limitation the nitrogen proportion decreases to $1 \%$ and the major proportion of carbon is assimilated into carbohydrates and lipids rather than into proteins. During this process the carbon to nitrogen ratio of phytoplankton shifts from 5 to 10 (Morris 1981, Wheeler 1983).

In the light of the importance of the nitrogen cycle for marine ecosystems we tried to simplify the complex scenario of individual amino acids by calculating the carbon to nitrogen ratio from these compounds. It is the purpose of the present paper to elaborate some general phenomena from the individual amino acid patterns occurring during phytoplankton blooms. Two different systems were investigated: (a) a classical type of spring phytoplankton bloom dominated by Chaetoceros species in the northern North Sea (Fladen Ground Experiment) (Hammer et al. 1983); (b) a bloom of a Thalassiosira rotula monoculture which was enclosed in large flexible plastic bags in the German Bight (Helgoland Harbour) (Hammer \& Eberlein 1981). This simplified system excluded a good part of biological and physical interactions, and reduced stress factors which were known to interfere with laboratory scale experiments (Williams 1981).

\section{MATERIALS AND METHODS}

Natural ecosystems. During the Fladen Ground Experiment 1976 (FLEX) in the Northern North Sea at a fixed station $\left(58^{\circ} 55^{\prime} \mathrm{N}, 0^{\circ} 32^{\prime} \mathrm{E}\right)$ a detailed data set from the spring phytoplankton bloom was obtained. On the

Table 1a. Sampling profiles and events during Fladen Ground Experiment. m.l.: mixed layer; 1.1.: lower layer

\begin{tabular}{|c|c|c|}
\hline $\begin{array}{l}\text { Sampling } \\
\text { profile no. }\end{array}$ & $\begin{array}{l}\text { Date } \\
(1976)\end{array}$ & Conditions \\
\hline 1 & $26 \mathrm{Mar}$ & Mixed water column \\
\hline 2 & $12 \mathrm{Apr}$ & \\
\hline 3 & $20 \mathrm{Apr}$ & Formation of the thermocline \\
\hline 4 & $22 \mathrm{Apr}$ & Exponential phytoplankton growth \\
\hline 5 & 24 Арг & DFAA maximum (m.1.) \\
\hline 6 & $26 \mathrm{Apr}$ & $\begin{array}{l}\text { Slight increase of paticulate } \\
\text { matter (1.1.) }\end{array}$ \\
\hline 7 & $28 \mathrm{Apr}$ & DFAA maximum (I.I.) \\
\hline 8 & 2 May & Steady state growth phase (m.l.) \\
\hline 9 & 9 May & Decrease of particulate matter (m.1.) \\
\hline 10 & 15 May & End of first plankton bloom (m.l.) \\
\hline
\end{tabular}

Table 1b. Events during an enclosed culture experiment with Thalassiosira rotula

\begin{tabular}{|cl|}
\hline Date (1973) & \multicolumn{1}{c|}{ Conditions } \\
\hline 27 Jun & Seawater filtration and enclosure filling \\
28 Jun & Nutrient enrichment and inoculation \\
29 Jun & Begin of exponential growth \\
30 Jun & DFAA increase \\
1 Jul & Nutrient limitation, end of exponential growth \\
\hline
\end{tabular}

R.V. Meteor and R.V. Anton Dohrn cruises samples were taken at $12.00 \mathrm{~h}$ GMT with 101 Niskin samplers at $3,10,20,30,40,50,60,70,80,100$ and $145 \mathrm{~m}$ depth. Mean values were computed for the water column above (mixed layer) and below (lower layer) the thermocline depths. The thermocline was defined as the maximum temperature gradient and based on the data from Soetje \& Huber (1980). Sampling profiles and conditions are listed in Table $1 \mathrm{a}$.

Samples were divided for phytoplankton and chemical investigations. An aliquot was passed through glass fibre filters (Whatman GF/C) and split for nutrient and amino acid analysis. Inorganic nutrients (ammonium and nitrate+nitrite) were measured immediately with an autoanalyser (Eberlein et al. 1983). Dissolved free amino acid (DFAA) samples were fixed by addition of $3 \mathrm{ml}$ of $3.5 \% \mathrm{HgCl}_{2}$ solution per litre and kept at $4{ }^{\circ} \mathrm{C}$ until analysis by cation exchange chromatography (Hammer \& Eberlein 1981). This method avoids any pre-concentration procedures, which are known not to be reproducible. The detection limit lay in the picomole range with a standard deviation of $\pm 9 \%$. Sample preparation, amino acid analysis and development during the experiments were described by Hammer \& Eberlein (1981). Particulate material on the glass fibre filters was deep frozen and dried at $50^{\circ} \mathrm{C}$ before analysis of nitrogen with a CHN analyser.

Enclosure experiments. Monoculture experiments with the diatom Thalassiosira rotula were carried out in June-July 1973 in large plastic enclosures ( 3 to $4 \mathrm{~m}^{3}$ ) in the German Bight (Helgoland harbour). Samples were taken at $2 \mathrm{~h}$ intervals. Experimental conditions (Table 1b) were published by Brockmann et al. (1977).

From the amino acid data sets atomic carbon to nitrogen $(\mathrm{C} / \mathrm{N})$ ratios were calculated considering the distribution of the following 18 individual amino acids: alanine (ala), $\beta$-alanine ( $\beta$-ala), arginine (arg), aspartic acid (asp), glutamic acid (glu), glycine (gly), histidine (his), leucine (leu), isoleucine (ile), lysine (lys), hydroxy-lysine (hy-lys), methionine (met), ornithine (orn), phenylalanine (phe), serine (ser), threonine (thr), tyrosine (tyr) and valine (val). For Table 4 the same amino acids were used for calculating the $\mathrm{C} / \mathrm{N}$ ratio of 
DFAA concentrations found in the literature unless otherwise noted.

The plankton data set was kindly provided by $M$. Gillbricht. The samples were bottled directly after sampling and preserved with Lugol solution. The number of individuals was transformed into $\mu \mathrm{g} \mathrm{C} \mathrm{dm}^{-3}$ (Gassmann \& Gillbricht 1982).

\section{RESULTS AND DISCUSSION}

During the Fladen Ground Experiment 1976 (FLEX) the classical type of spring phytoplankton bloom could be investigated. The biological and chemical situation
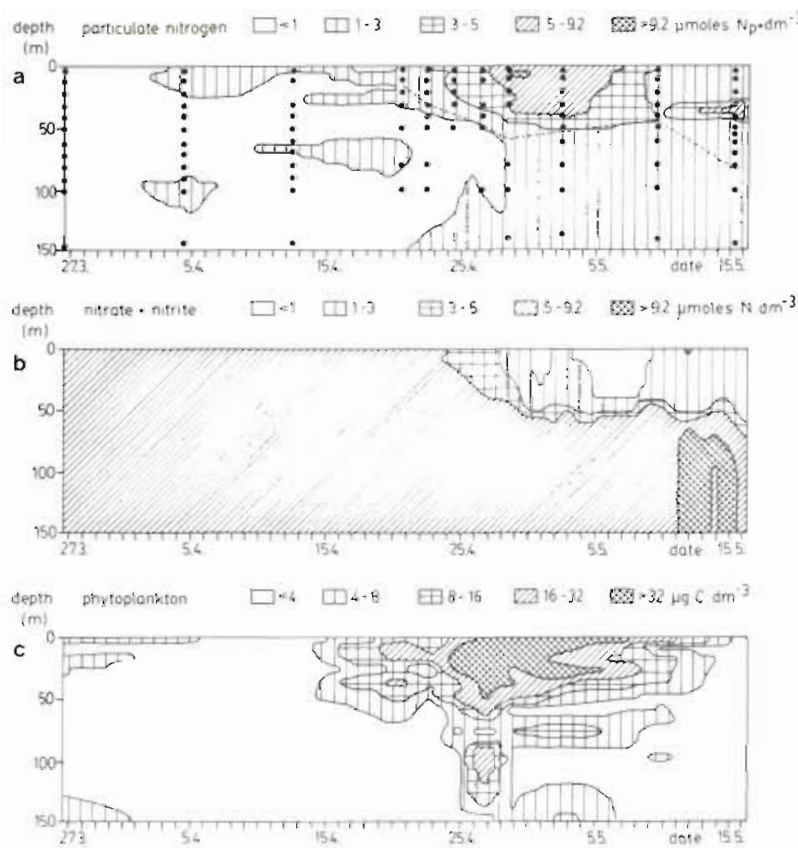

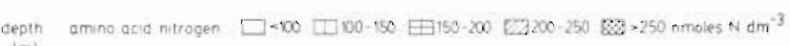

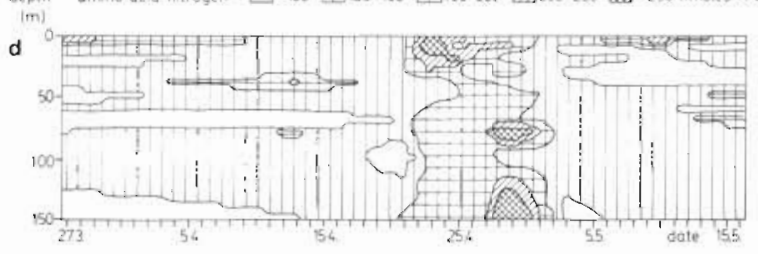

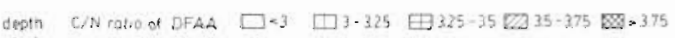

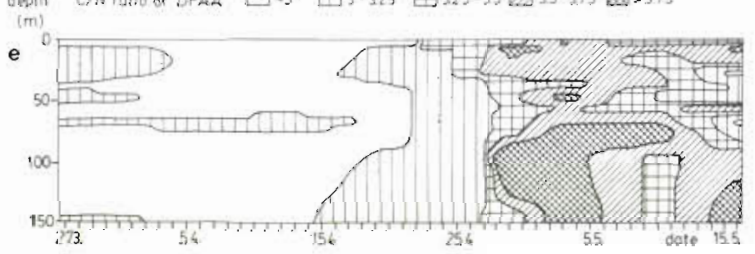

Fig. 1. Biological and chemical situation during FLEX (1976). (a) Particulate nitrogen (data from W. Hickel and P. Weigel); (๑) sampling depth; (--) thermocline. (b) Nitrate + nitrite. (c) Phytoplankton carbon (data from M. Gillbricht). (d) Total dissolved free amino acid nitrogen. (e) Carbon to nitrogen ratio of total dissolved free amino acids is characterized in Fig. 1. With the formation of the thermocline around April 20 (Fig. 1a) phytoplankton growth started. Subsequently the thermocline stabilized at about $50 \mathrm{~m}$ depth and in the water column above - the so-called mixed layer - the phytoplankton reached a maximum about $10 \mathrm{~d}$ later at the beginning of May (Fig. 1c). At the same time inorganic nitrate+nitrite was transformed into organic bound particulate nitrogen (Fig. 1a, b) nearly quantitatively (Eberlein et al. 1980). During that time numbers of heterotrophic bacteria were at a relatively low level of about 2 colony forming units (CFU) per ml (Hentzschel 1980 ).

From May 5 particulate material was reduced again to very low levels probably due to sedimentation (Hammer et al. 1983, Davies \& Payne 1984) and grazing (Krause \& Trahms 1983).

The observed phenomena could have been partly caused by hydrodynamic processes, but biological, chemical and physical parameters suggest that to a significant extent the measured data may be attributed to biological rather than to hydrodynamic interactions (Hammer et al. 1979, Hentzschel 1980, Soetje \& Huber 1980, Krause \& Trahms 1983, Brockmann et al. 1983).

The distribution of dissolved free amino acids (DFAA) and their carbon to nitrogen ratio $(\mathrm{C} / \mathrm{N})$ looks rather heterogeneous (Fig. 1d, e). It becomes clearer by calculating mean values of DFAA nitrogen and the corresponding $\mathrm{C} / \mathrm{N}$ ratios for the water column above (mixed layer, Fig. 2a) and below (lower layer, Fig. 2b) the thermocline. In both layers the $\mathrm{C} / \mathrm{N}$ ratios of DFAA had a steady increase from the start until the end of the bloom (May 2). Though the DFAA concentrations were relatively constant, the drastic $\mathrm{C} / \mathrm{N}$ shift pointed to high amino acid turnover which lasted from April 22 to May 15. The well-balanced uptake and release processes showed significant DFAA concentration maxima only on April 22 (mixed layer) and April 28 (lower layer). It is striking that the 2 maxima (mixed and lower layer) had a different amino acid composition represented by different ratios (3.16 and 3.71). The increasing ratio was mainly influenced by increasing glutamic acid and aspartic acid and decreasing ornithine, serine (above $50 \mathrm{~m}$ ), threonine (above $50 \mathrm{~m}$ ) and valine (below $50 \mathrm{~m}$ ) (Tables $2 \& 3$ ).

If selective chemical and physical processes are excluded, the increase of the $\mathrm{C} / \mathrm{N}$ ratio could be caused by 3 different processes which in most cases are probably all involved: (1) selective uptake of low ratio DFAA by heterotrophs; (2) different excretion patterns caused by changes of the physiological state of the plankton community; (3) two or more sources, which release different (ratio) amino acids with a changing intensity.

Selective bacterial uptake was demonstrated by 
Gocke (1970), Williams \& Yentsch (1976) and Amano et al. (1982). However, bacterial numbers first increased after the phytoplankton bloom (Hentzschel 1980), and bacterial activity might not have been significant during the blooms. On the other hand, real bacterial numbers are underestimated when the CFU method is applied.
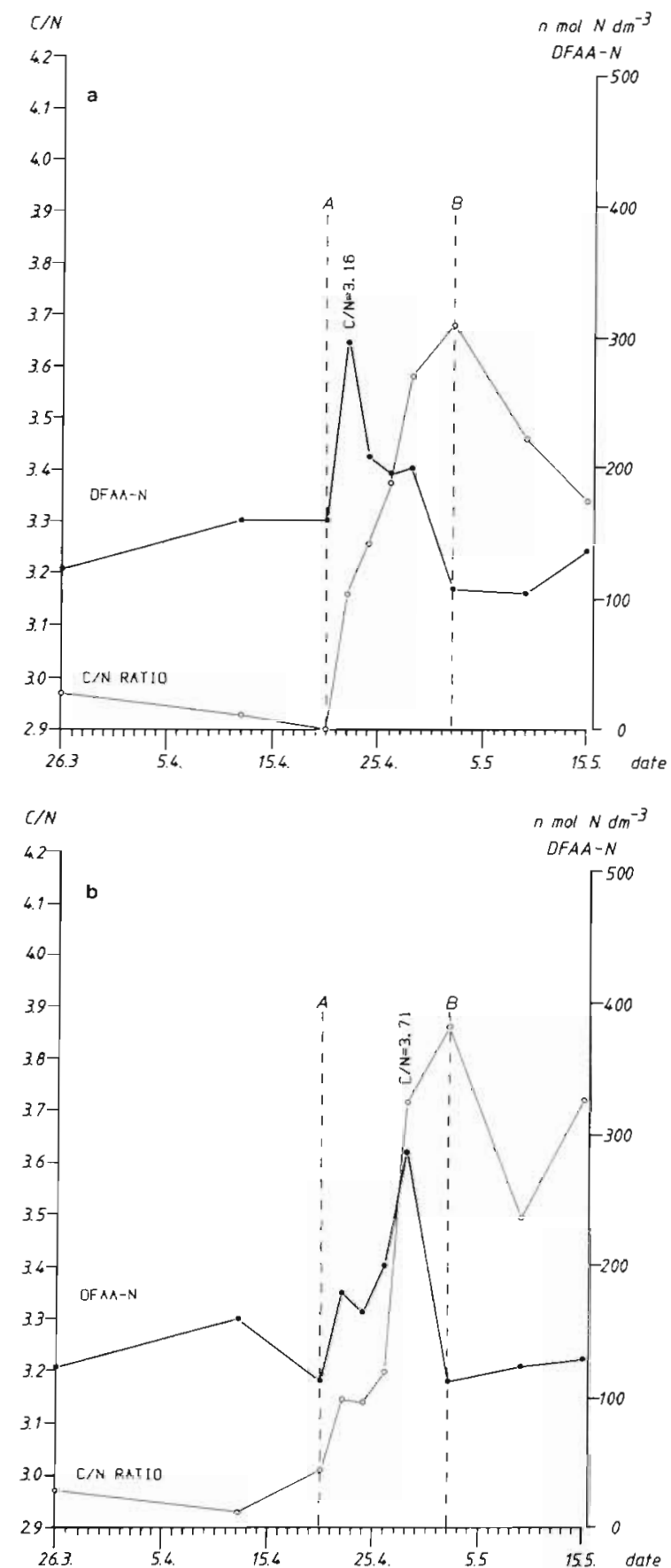

Fig. 2. Integrated mean values of dissolved free amino acid concentration (DFAA) and carbon to nitrogen $(\mathrm{C} / \mathrm{N})$ ratios $(a)$ above and (b) below the thermocline (FLEX 1976). A: begin of exponential growth phase; $\mathrm{B}$ : begin of steady state phase
Table 2. Rank-correlations (after Spearman) between biological and chemical parameters during FLEX spring bloom (Apr 16 to May 2, 0 to $50 \mathrm{~m}$ ). Abbreviations: DFAA: dissolved free amino acids; $\mathrm{C} / \mathrm{N}$ : carbon to nitrogen ratio of $\mathrm{DFAA}_{;} \mathrm{NO}_{3}$ : nitrate + nitrite; $\mathrm{NH}_{4}$ : ammonium; $\mathrm{N}_{p}$ : particulate nitrogen; Phy: total phytoplankton; Per: peridineans; Fla: phyto-flagellates. Positive correlations: $(\square) p=0.01 ;(\bullet) p=0.05$. Negative correlations: $(\square) \mathrm{p}=0.01_{\mathrm{i}}(0) \mathrm{p}=0.05$. For abbreviations of amino acids see 'Materials and Methods'

$$
\text { o. } 50 \mathrm{~m} \text { depth }
$$

\begin{tabular}{|c|c|c|c|c|c|c|c|c|c|c|c|c|c|c|c|c|c|}
\hline & & a & & & 8 & & है। & & & $\frac{\pi}{4}$ & & & $\hat{\imath}^{0} \frac{x}{3}$ & & & $\frac{a}{a} a_{a}^{a}$ & \\
\hline & & & 0 & $\cdot$ & & & & & & & & & 0 & $\bullet$ & $\bullet$ & & Fla \\
\hline & & & & & 10 & & & & & & & & 0 & $\pi$ & $\bullet$ & & $\rho_{e r}$ \\
\hline & $\bullet$ & $\bullet$ & $\square$ & & & 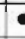 & 0 & & & & a & I & व $\bullet$ & a & & & Dia \\
\hline & & & - & $\bullet$ & & 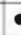 & & & & & 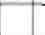 & & 0 & & & & 200 \\
\hline & $\bullet$ & & 0 & & & 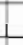 & 0 & & & & $=$ & 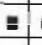 & 므 & & & & $P_{h y}$ \\
\hline a & & & ㅁ & ㅁ & & 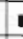 & & & & 0 & & & & & & & $\mathrm{NH}$ \\
\hline & 0 & & $\square$ & $\bullet$ & & D & T. & & & & 口 & ㅁ & & & & & no \\
\hline & $\bullet$ & & $\square$ & & & 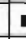 & 10 & & & & \begin{tabular}{|l|} 
\\
\end{tabular} & & & & & & $N_{\rho}$ \\
\hline & 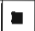 & & (1) & $\circ$ & 0 & & 0 & & & & & & & & & & $10 \pi$ \\
\hline
\end{tabular}

Table 3. Rank-correlations (after Spearman) between biologi$\mathrm{cal}$ and chemical parameters during FLEX spring bloom (Apr 16 to May 2, 60 to $150 \mathrm{~m}$ ). See Table 2 for explanations $60-150 \mathrm{~m}$ depth

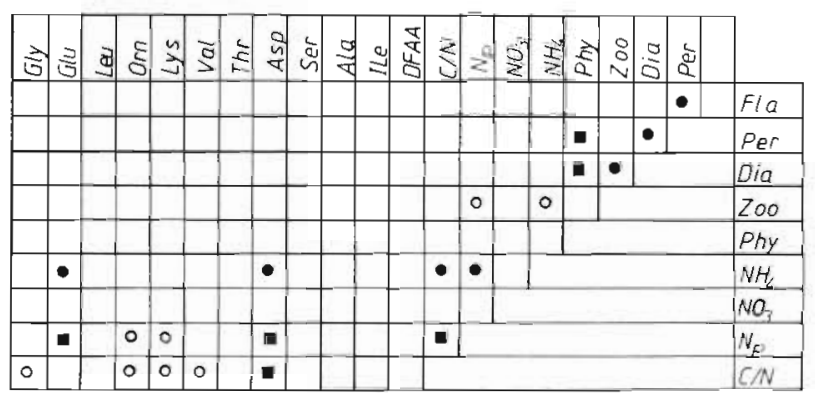

In the euphotic zone the major portion of plankton carbon (mean of $52 \%$ from March 26 to May 15) was represented by diatoms (Fig. 3b), mainly Chaetoceros species (Gieskes \& Kraay 1980). Peridinean populations $(33 \%)$ developed earlier and were distributed down to greater depths (Fig. 3c) than diatoms. Phytoflagellates $(6 \%)$ and zooplankton $(9 \%)$ had a nearly similar distribution developing before the diatom bloom with maximum values in the upper part of mixed layer (Fig. 3d, e).

In Tables 2 and 3 rank correlations between biological and chemical parameters are presented for the 0 to $50 \mathrm{~m}$ and 60 to $150 \mathrm{~m}$ water column separately. For the mixed layer positive correlations existed between the total phytoplankton biomass and its 3 main groups the diatoms, peridineans and flagellates, but not between the groups themselves. Also zooplankton showed correlations with peridineans as well as flagellates. Particulate nitrogen (Fig. 4a) was mainly produced by phytoplankton (Fig. 3a), especially diatoms (Fig. 3b), 
and these parameters were negatively correlated with nitrate+nitrite (Fig. 4b, Table 2).

It is obvious that the spatial and temporal distribution of individual amino acids (Fig. 4f to p) showed a
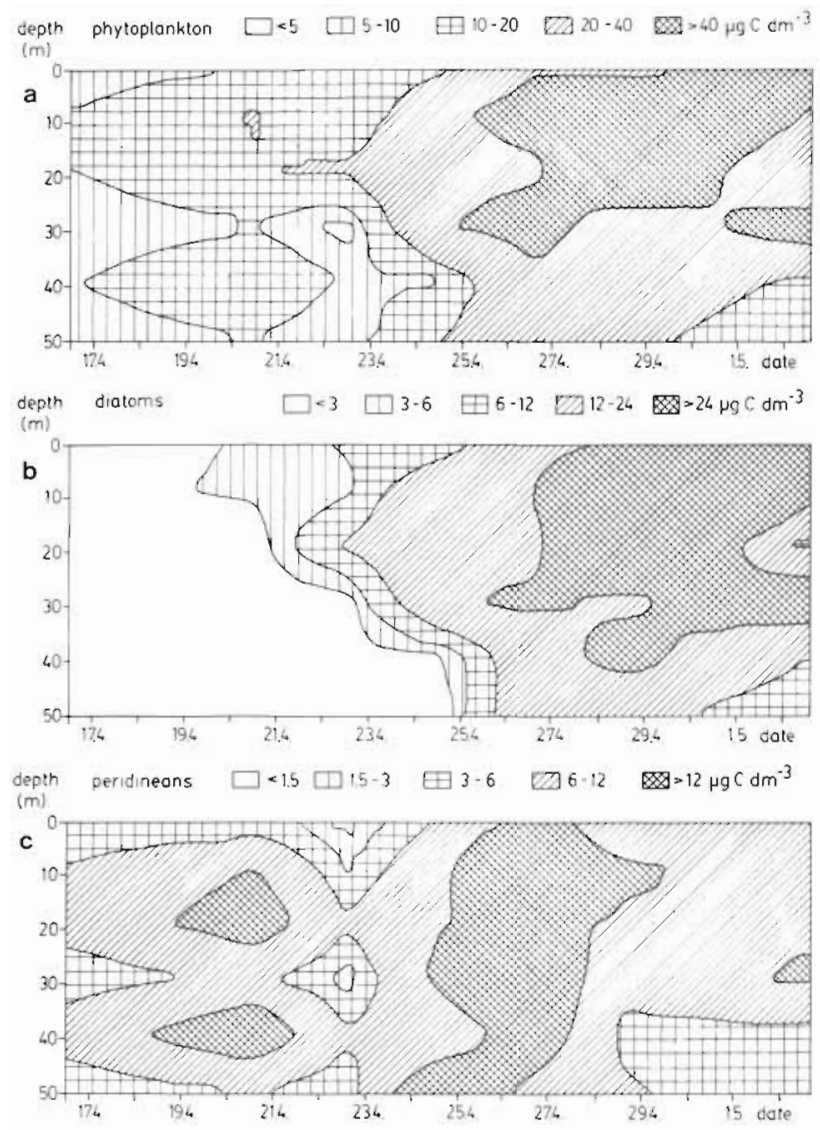

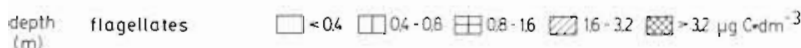

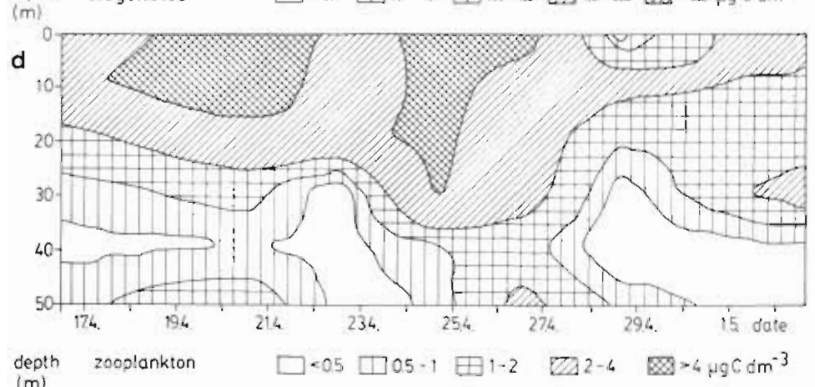

(m)

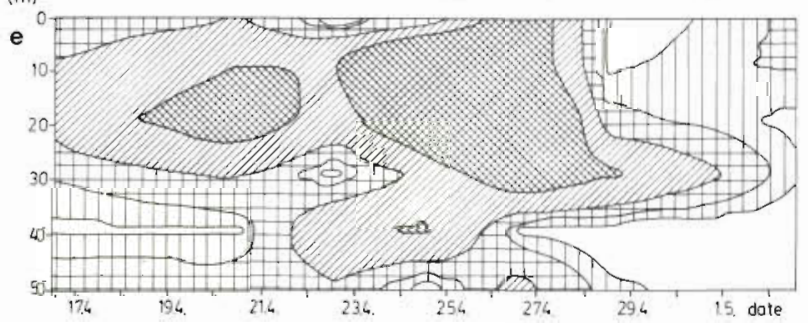

Fig. 3. Plankton distribution during exponential growth phase in the euphotic zone (FLEX 1976). (Data from M. Gillbricht.) (a) Phytoplankton (total). (b) Diatoms. (c) Peridineans. (d) Phytoflagellates. (e) Zooplankton succession that was comparable to the plankton situation (Fig. 3). Diatoms were correlated positively with glutamic acid, aspartic acid and leucine, and negatively with ornithine and serine; peridineans negatively with threonine; flagellates positively with ornithine and lysine; and zooplankton positively with ornithine, lysine and aspartic acid (Table 2). The $\mathrm{C} / \mathrm{N}$ ratio of DFAA, representing the composition of all individual amino acids, showed positive correlations only with the diatoms (Fig. $3 b$ \& 4 e). Interrelations with other members of the plankton community were not significant.

Selective DFAA uptake by phytoplankton has often been reported (Wheeler et al. 1974, 1977, Lu \& Stephens 1984, 1985, Admiraal et al. 1984, Flynn \& Syrett $1986 a$, b). Uptake is controlled by different carrier systems which can be partly activated by nitrogen and/or carbon depletion and reduced photosynthesis (darkness) (Bonin \& Maestrini 1981, Wheeler 1983, Flynn \& Syrett 1985). For example, Nitzschia ovalis could be shown to have at least 3 amino acid uptake systems which are specific for the transport of acidic, polybasic and neutral amino acids. While the polybasic amino acid carrier system is present throughout all phases of growth, neutral and acidic amino acids are taken up only during nitrogen depletion (North \& Stephens 1972). Since the uptake systems may differ among the species, the momentary DFAA composition will enhance the development of particular components of the plankton community. But most of the uptake experiments were performed under laboratory scale in which high concentrations were often supplied. There is also some evidence for uptake by nearshore marine phytoplankton (Lu \& Stephens 1984, Admiraal et al. 1984). DFAA concentrations during FLEX were very low (Fig. 4d), which is typical for the open sea, and there is considerable doubt if under these conditions phytoplankton plays a significant part in DFAA turnover (Paul 1983).

From the highly significant negative correlation of the DFAA C/N ratio with nitrate+nitrite (Fig. $4 \mathrm{~b}$, e, Table 2) the increasing DFAA C/N ratio in the mixed layer could be explained by an adaption of the diatoms to the exhausted inorganic nitrogen source keeping nitrogen losses at a low level during DFAA exudation. Exudation or excretion of DFAA from healthy phytoplankton has been controversial for a long time (Fogg 1977. Sharp 1977, Mague et al. 1980, Hammer et al. 1981, Fogg 1983). When using monocultures of the diatom Thalassiosira rotula in large enclosures to simplify the natural system (Brockmann et al. 1977), a comparable shift in the DFAA C/N ratio occurred. The time courses of changes in particulate nitrogen, nitrate+nitrite, DFAA and $\mathrm{C} / \mathrm{N}$ ratio of DFAA are presented in Fig. 5. Experimental conditions as well as 


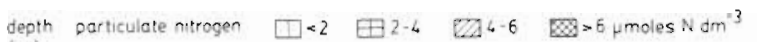

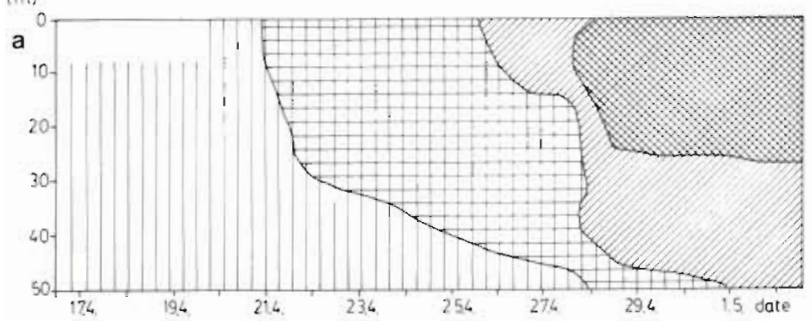

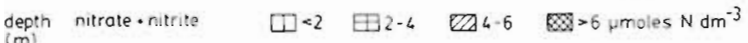

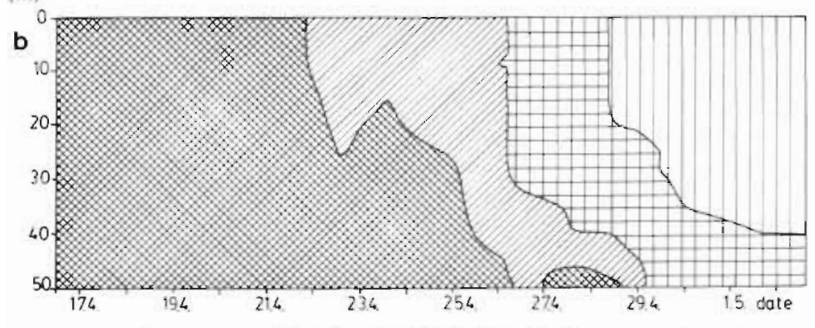

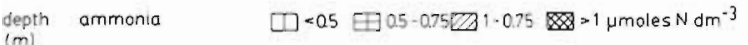

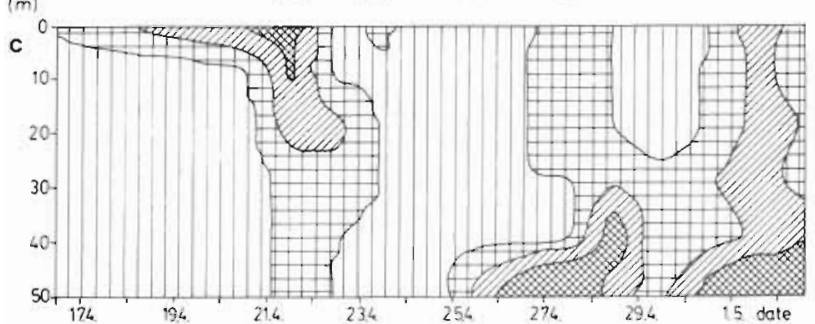

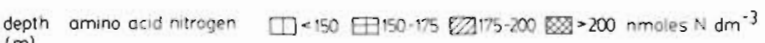

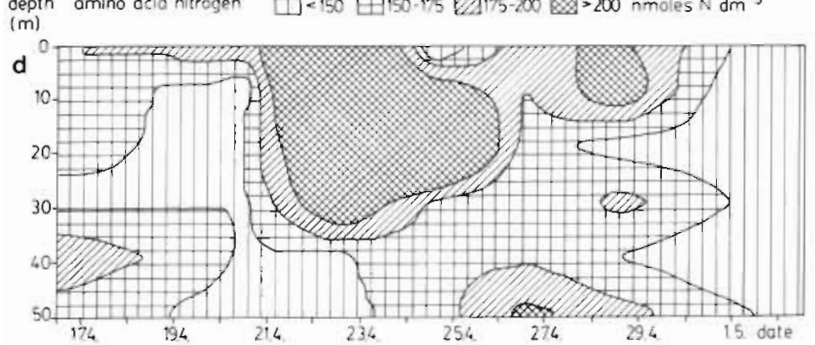

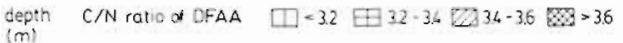

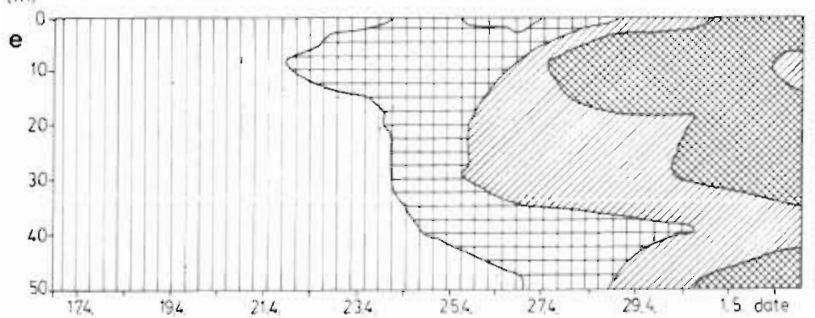

depth serme $\square 0-20$ \#20-60 B B $40-60$ 国>60 nmoles $\mathrm{dm}^{-3}$

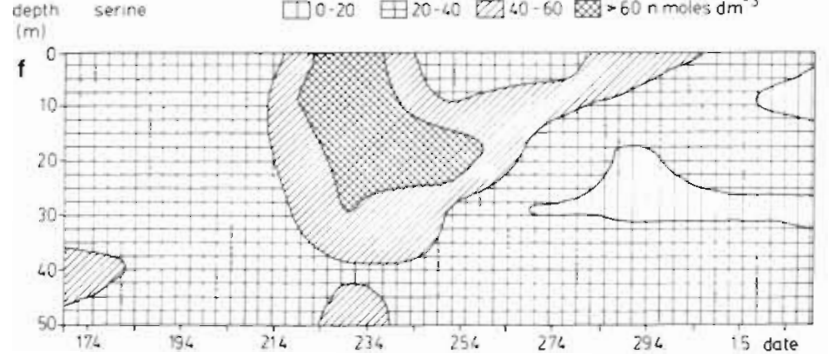

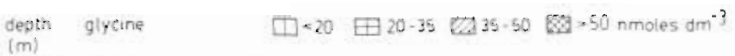

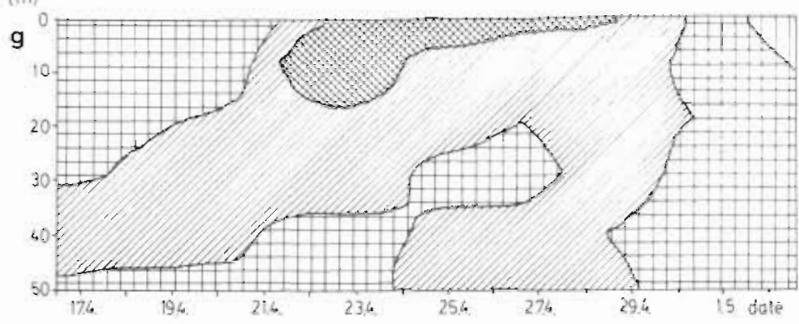

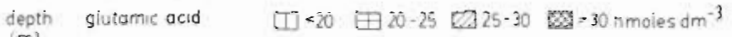

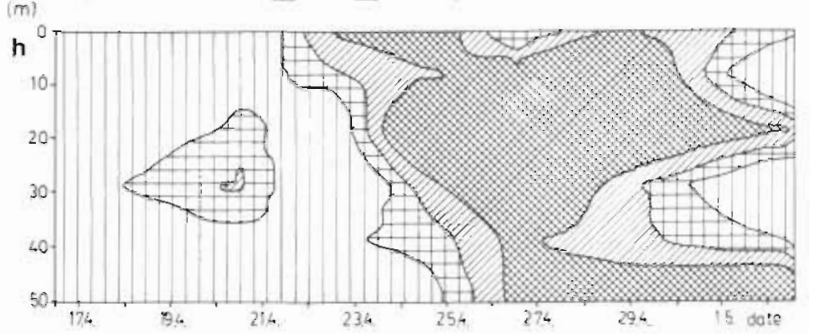

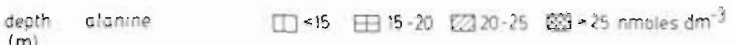

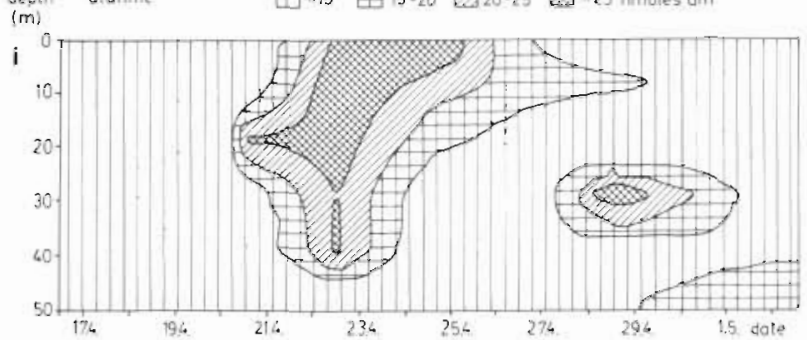

depth osparticaerd $\square<5 \quad \boxplus 5-10 \quad \square 10-45 \quad \mathbb{2} \times 15$ nmoles $\mathrm{dm}^{-3}$

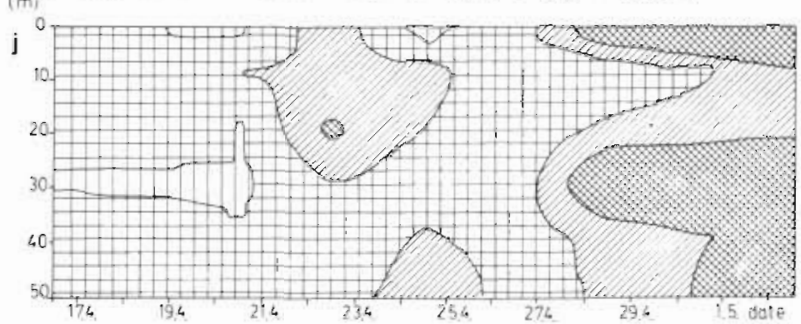

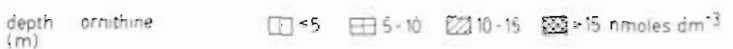

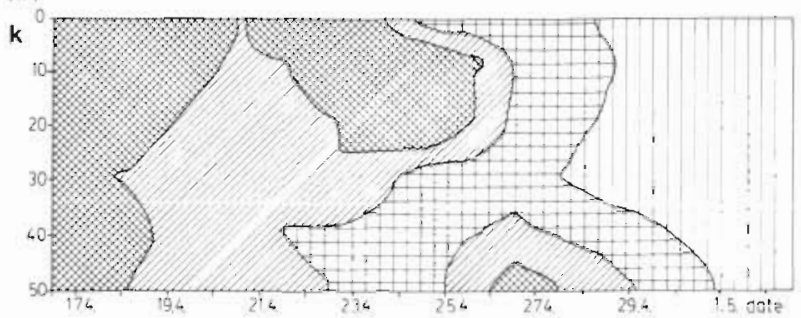

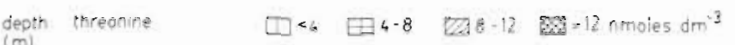

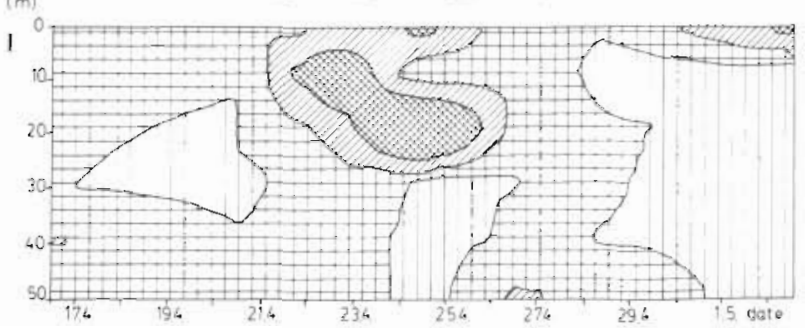



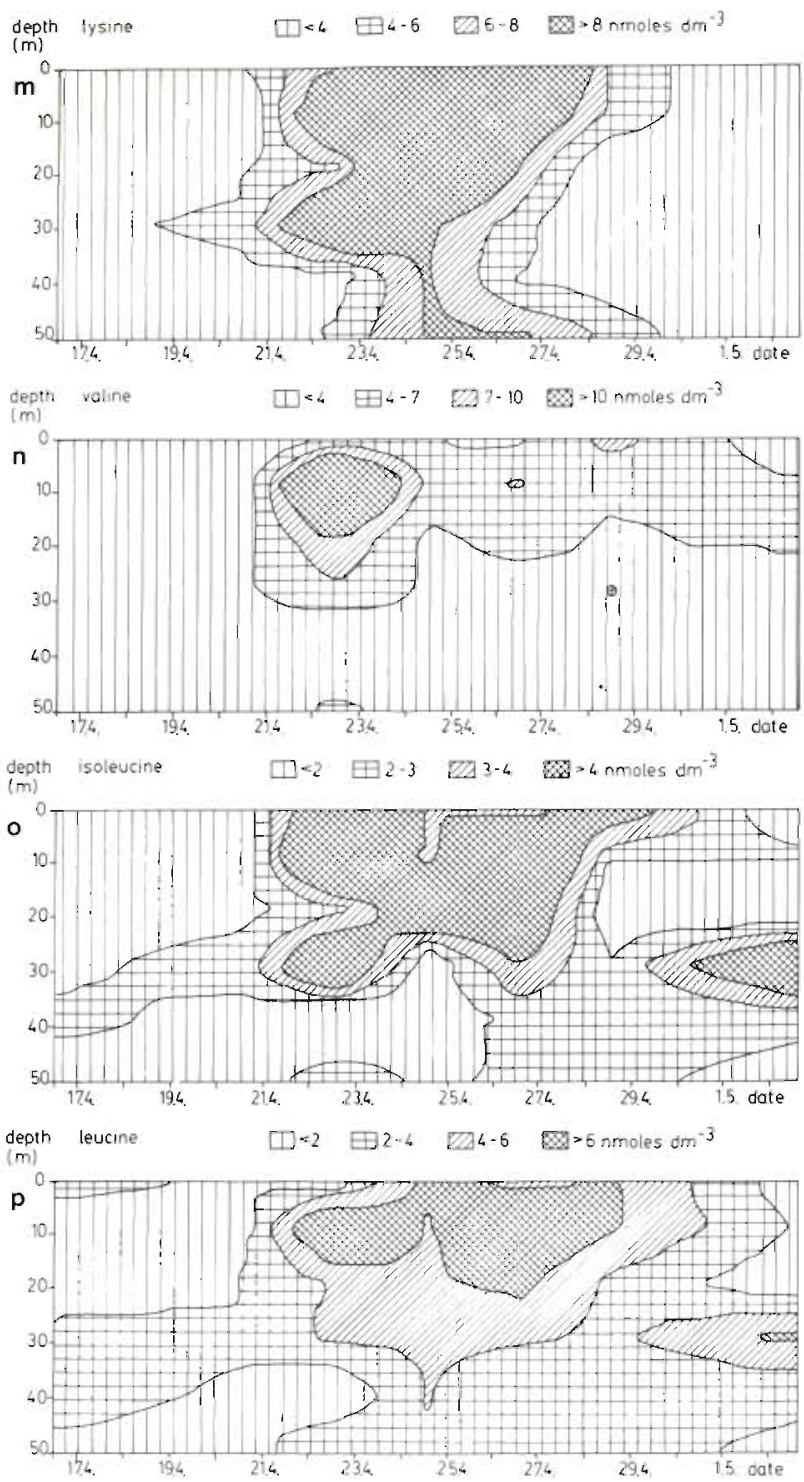

Fig. 4. Chemical situation during exponential growth phase in the euphotic zone (FLEX 1976). (a) Particulate nitrogen. (b) Nitrate + nitrite. (c) Ammonia. (d) Dissolved free amino acid nitrogen. (e) Carbon to nitrogen $(\mathrm{C} / \mathrm{N})$ ratio of dissolved free amino acids. (f) Serine. (g) Glycine. (h) Glutamic acid. (i) Alanine. (j) Aspartic acid. (k) Ornithine. (l) Threonine. (m) Lysine. (n) Valine. (o) Isoleucine. (p) Leucine

formation of individual amino acids, cell counts, bacteria etc. were described previously (Hammer \& Eberlein 1981). Unlike the natural system (FLEX), in which the DFAA C/N ratio started at about 3.0, the enclosure was filled with June waters which - probably after phases of previous biological productivity - already contained high $\mathrm{C} / \mathrm{N}$ ratio amino acids, but at low concentrations (Fig. 5b). During the early exponential growth of $T$. rotula these low initial concentrations of high ratio DFAA were successively overlaid by low ratio amino acids, released by the diatoms. The result
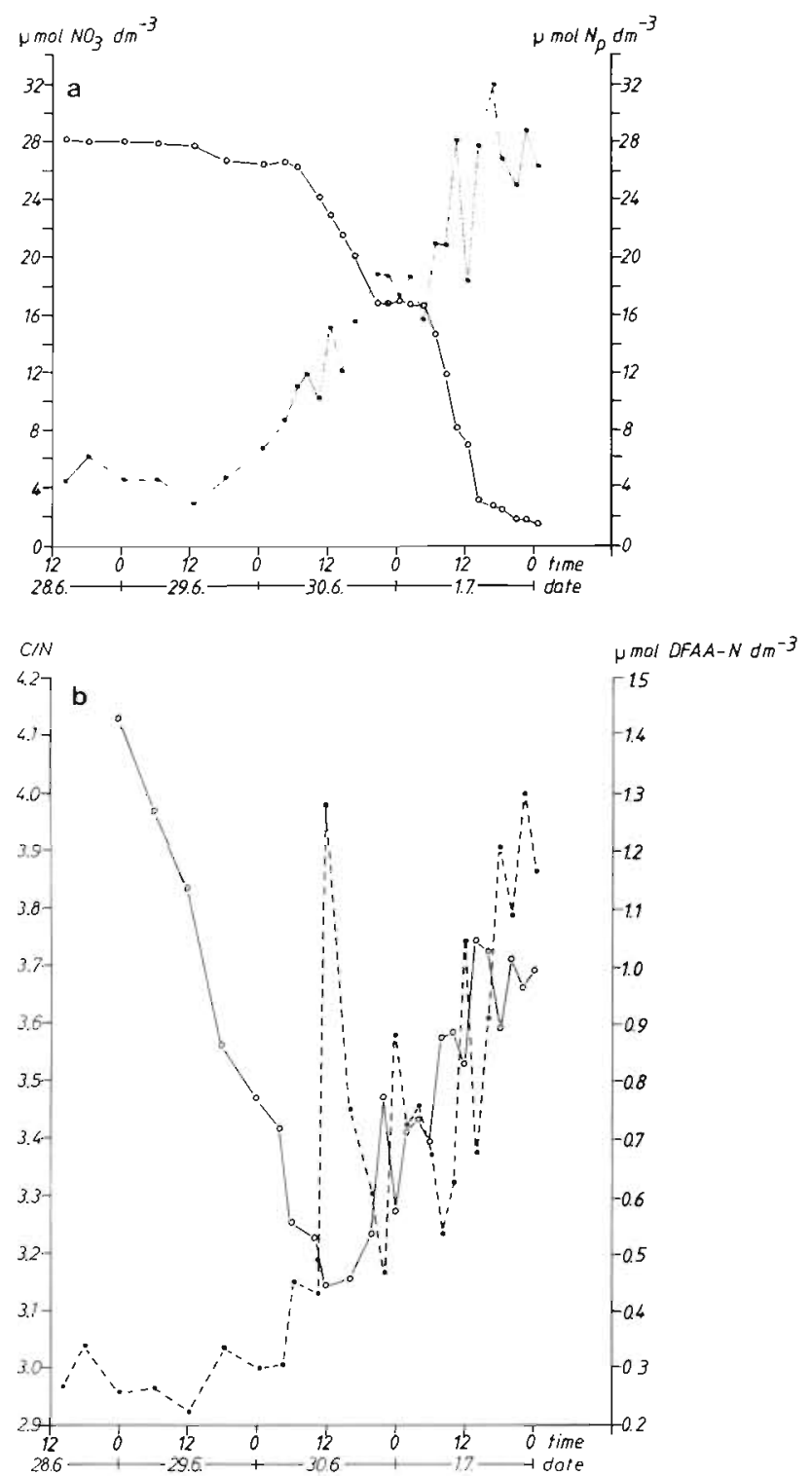

Fig. 5. Enclosed culture of Thalassiosira rotula. Development of (a) nitrate $\left(\mathrm{O}^{-} \mathrm{O}\right)$ and particulate nitrogen $(\cdots \bullet)$ and (b)

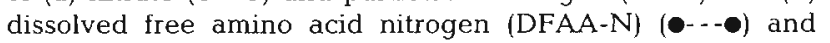
carbon to nitrogen ratio $(\mathrm{C} / \mathrm{N})$ of DFAA $(\mathrm{O}-\mathrm{O})$

was an increase in concentration and a reduction of the ratio. During the later part of the bloom there was a slow ratio shift to higher values. The increasing DFAA (Fig. 5b) showed strong short-term fluctuations as a result of release and uptake processes. In the case of individual amino acids with a ratio of 4.0 or less the release intervals were proved to be linked to the synchronized physiological state of the diatoms (Hammer \& Brockmann 1983). Negative correlation $(\mathrm{p}=$ 0.01 ) between DFAA short-term release and $\mathrm{C} / \mathrm{N}$ ratio becomes evident, if one compares the rates per hour (Fig. 6). From these facts we assume that amino acids excreted by $T$. rotula during the synchronized release 


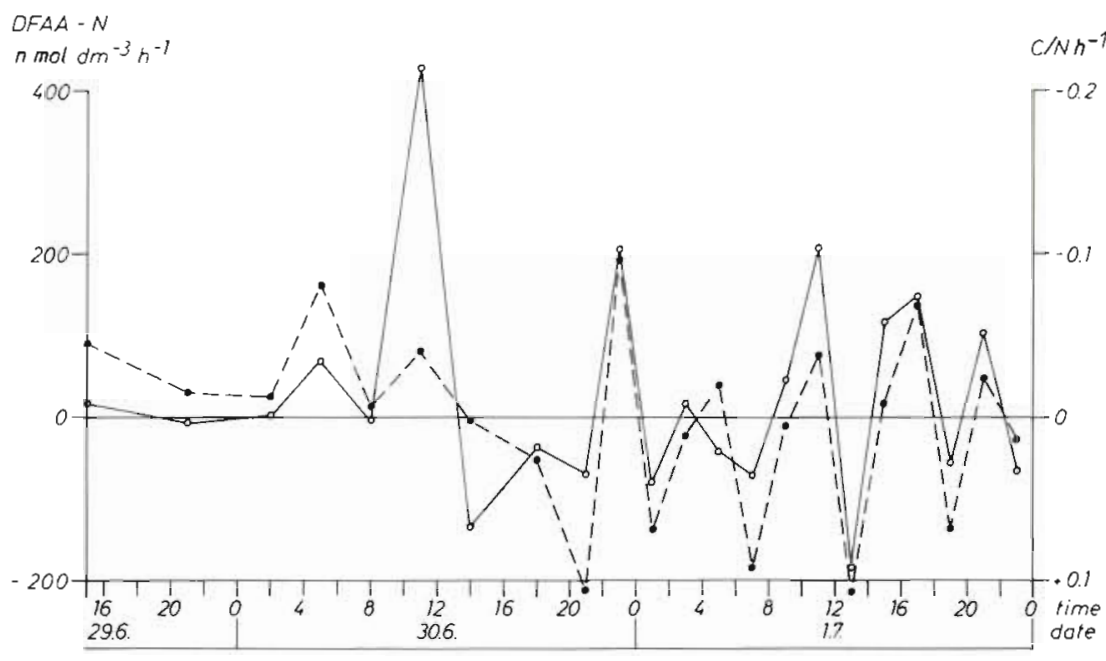

Fig. 6. Enclosed culture of Thalassiosira rotula. Concentration changes of dissolved free amino acid nitrogen (DFAA-N) $(-)$ and carbon to nitrogen ratio $(\mathrm{C} / \mathrm{N})$ of DFAA (---) (presented inversely) computed as rates per hour

phases must have a low $\mathrm{C} / \mathrm{N}$ ratio. Comparable results were reported from axenic batch cultures of the diatom Chaetoceros debilis during different growth phases (Poulet \& Martin-Jézéquel 1983). The proportions of several amino acids changed according to the development of the diatoms. From the data set a shift of the DFAA C/N ratio from 3.24 to 3.81 can be calculated for the exponential to the stationary growth phase (phe + $\mathrm{NH}_{4}^{+}$was not taken into consideration because of incomplete separation).

'Sloppy feeding' by zooplankton may also be responsible for the release of DFAA into the seawater (Mopper \& Linroth 1982). During FLEX zooplankton carbon made up $8.7 \%$ of the total plankton carbon. The DFAA C/N ratio was not correlated with zooplankton, but aspartic acid, lysine and, with high significance, ornithine showed positive correlations
(Table 2). The presence of ornithine may indicate digestion of proteinaceous material by zooplankton (Williams \& Poulet 1986). But ornithine could also be derived from the algal exoenzyme arginase activity on arginine as suggested by Degens (1970). Negative correlation with diatoms supports this assumption (Table 2).

Table 4 gives a short review of $\mathrm{C} / \mathrm{N}$ ratios calculated from literature amino acid data which may be representative for different sources of DFAA. The upper part shows the ratio of monomeric acids as cell-content of mixed phyto- and zooplankton populations at different seasons and in different waters. The ratio for amino acid extracts from cell water of Phaeodactylum tricornutum is also given. The ratio of all these cell-pool amino acids seems to be relatively constant at about 3.0. The lower part of Table 4 shows ratios for total

Table 4. Amino acid $\mathrm{C} / \mathrm{N}$ ratios calculated from literature data

\begin{tabular}{|c|c|c|}
\hline Source & $\mathrm{C} / \mathrm{N}$ ratio (atomic) & Reference \\
\hline \multicolumn{3}{|l|}{ Cell pool free amino acids } \\
\hline \multicolumn{2}{|l|}{ Mixed phytoplankton + microzooplankton } & \multirow[t]{5}{*}{ Jeffries (1969) } \\
\hline Winter-spring, Stn A & $3.06^{a}$ & \\
\hline Winter-spring, Stn B & $3.01^{\circ}$ & \\
\hline Summer-fall, Stn A & $\begin{array}{l}2.90^{a} \\
2.92^{d}\end{array}$ & \\
\hline Summer-fall, Stn B & $2.92^{a}$ & \\
\hline Phaeodactylum tricornutum & $3.03^{\mathrm{e}}$ & Lu \& Stephens (1984) \\
\hline \multicolumn{3}{|l|}{ Total amino acids } \\
\hline Diatoms (average of 6 species) & $3.60^{-6, b}$ & Chuecas \& Riley (1969) \\
\hline Diatom cell wall (average of 6 species) & $3.86^{a, b . c}$ & Hecky et al. (1973) \\
\hline Diatom cell contents (average of 6 species) & $4.26^{a, b, c}$ & Hecky et al. (1973) \\
\hline Pyrosoma & $3.85^{a, b}$ & Raymont et al. (1975) \\
\hline Particulate matter (Pacific) & $4.23^{s, b, c, d}$ & Siezen \& Mague (1978) \\
\hline Whole casein & $4.39^{a, b, c}$ & Gordon \& Whittier (1965) \\
\hline $\begin{array}{l}\text { a Without } \beta \text {-ala Without hy-lys } \\
\text { e Additional asn and gln; without } \beta \text {-ala, his, hy-ly }\end{array}$ & $\begin{array}{l}\text { orn Witho } \\
n, \text { phe and thr }\end{array}$ & is and arg \\
\hline
\end{tabular}


amino acids, of which the main part are peptid bound amino acids from cell proteins. In all these cases the ratio is at a higher level $(\geqslant 3.6)$. Thus during exponential growth the low ratio of extracellular DFAA was the result of a liberation from an intracellular amino acid pool rather than from proteolytic activity on dead proteinaceous material.

Diatoms are characterized by a relative abundance of serine compared to other phytoplankton species (Chau et al. 1967. Chuecas \& Riley 1969). Therefore another possible origin of low ratio amino acids might be the synthesis of the diatom cell-wall. In the cellwall model of Hecky et al. (1973), the silica frustule is connected to a protein template, which would be distinguished by its high serine content and further by threonine and glycine. One can assume that part of these low $\mathrm{C} / \mathrm{N}$ ratio amino acids might be lost during the synthesis of the cell-walls.

Summing up, a $\mathrm{C} / \mathrm{N}$ ratio shift of DFAA can be interpreted in the following way: the free amino acid pool in the algae has a ratio of about 3.0. During high productivity extracellular release from phytoplankton is a normal physiological process (Smith et al. 1977 , Mague et al. 1980). Huge intracellular amino acid pools can be accumulated and used for osmoregulation in phytoplankton (Ahmad \& Hellebust 1984). If, as a consequence of large productivity, the intracellular pool overflows, excretion as a bypass reaction may become necessary in order to balance the osmotic pressure of the cell (Hammer et al. 1981). Intracellular DFAA pools in phytoplankton are species and nutrient dependent and can vary between 0.9 and $26.4 \%$ of the particulate nitrogen. Depletion of inorganic nitrogen nutrients reduces the internal DFAA pool (Dortch et al. 1984) as well as synthesis of cell-wall material. In consequence, emission of low ratio amino acids decreased. After this phase of exudation first decay processes became more significant resulting in progressive proteolytic liberation of amino acids which have a higher $\mathrm{C} / \mathrm{N}$ ratio (Table 4 ).

During the FLEX phytoplankton bloom the DFAA maximum had a $\mathrm{C} / \mathrm{N}$ ratio of 3.16 in the mixed layer. This maximum occurred in the first part of the exponential growth phase and can be interpreted as an exudation maximum (Fig. 2a). The increasing $\mathrm{C} / \mathrm{N}$ ratio which appeared later indicated that release from decay processes now became dominant in the mixed layer. This was supported by the positive correlation with particulate nitrogen (Table 2).

In the lower layer the situation was different: hol a slight increase of particulate material occurred during the bloom around April 26 (Fig. 1a, c). The bulk of these substances was probably involved in sedimentation processes. Between April 19 and May 2, an estimated $28 \%$ of the daily flux of phosphate into particu- late material accumulated in the lower layer (Kattner et al. 1980). Davies \& Payne (1984) calculated about $35 \%$ of primary production as flux into the sediment between April 24 and May 19 and they found a large settlement of diatoms in their sediment traps immediately after the spring bloom (up to $40 \%$ of the sediment on May 2). Increase of nitrate + nitrite (Fig. 1b) and a positive correlation of ammonia with particulate nitrogen and $\mathrm{C} / \mathrm{N}$ ratio (Table 3) can be attributed to enhanced microbial activity on particulate material in the lower layer. The DFAA reached maximum concentrations during the late exponential growth phase (April 28; Fig. 2b). A C/N ratio of 3.71 supports the suggestion that these amino acids were originated by decay processes on particulate nitrogen (Table 3). Correlations between phytoplankton and amino acids were not significant in this layer.

\section{CONCLUSION}

The concentrations of dissolved free amino acids (DFAA) are relatively low in seawater, although because of their high turnover rates - they play an important role in nutrition of marine ecosystems. The purpose of this study was to demonstrate that in spite of the high variability of individual amino acids in seawater some general aspects can be found. Calculation of the DFAA C/N ratio from the different individual amino acids indicated that successions of these substances were well subordinated to a continuously increasing $\mathrm{C} / \mathrm{N}$ ratio in the course of diatom blooms. This ratio shift was suggested to be the result of different release mechanisms according to the physiological state of the plankton. It is obvious that, in spite of relatively constant DFAA concentrations in natural plankton ecosystems, phytoplankton blooms leave their 'finger prints' in the form of specific patterns of organic compounds distributed over the water column. These 'finger prints' still exist when the producing organisms have gone. Further investigations should be made in detecting inter-relations between biological succession and 'succession' of individual organic compounds during plankton blooms.

Acknowledgements. We thank Prof. Gillbricht who kindly provided the plankton data and Drs. W. Hickel and P. Weigel for the particulate nitrogen data. Thanks are also due to the FLEX team for their cooperation, $\mathrm{H}$. Wierhake and $\mathrm{H}$. Fichtner for technical assistance, R. Lucht for typing and G. Hermes for drawing the figures. This work was supported by the Deutsche Forschungsgemeinschaft, Sonderforschungsbereich 94, Meeresforschung, Hamburg. This is JONSDAP 76 Contribution No. 119. 


\section{LITERATURE CITED}

Admiraal, W., Laane, W. P. M., Peletier, H. (1984). Participation of diatoms in the amino acid cycle of coastal waters: uptake and excretion in cultures. Mar. Ecol. Prog. Ser. 15: 303-306

Ahmad, I., Hellebust, J. A. (1984). Osmoregulation in the extremely eurohaline marine micro-alga Chlorella autotrophica. Plant. Physiol. 74: 1010-1015

Amano, M., Hara, S., Taga, N. (1982). Utilization of dissolved amino acids in sea water by marine bacteria. Mar. Biol. 68: $31-36$

Bada, J. L., Lee, C. (1977). Decomposition and alternation of organic compounds dissolved in seawater. Mar. Chem. 5: $523-539$

Bonin, D. J., Maestrini, S. Y. (1981). Importance of organic nutrients for phytoplankton growth in natural environments: Implications for algal species succession. In: Platt, T. (ed.) Physiological bases of phytoplankton ecology. Can. Bull. Fish. Aquat. Sci. 210: 279-291

Brockmann, U. H., Eberlein, K., Hentzschel, G., Schöne, H., Siebers, D., Wandschneider, K., Weber, A. (1977). Parallel plastic tank experiments with cultures of marine diatoms. Helgoländer Meeresunters. 30: 201-216

Brockmann, U. H., Ittekot, V., Kattner, G., Eberlein, K., Hammer, K. D. (1983). Release of dissolved organic substances in the course of phytoplankton blooms. In: Sundermann, J., Lenz, W. (ed.) North Sea dynamics. Springer, Berlin, p. $530-548$

Chau, Y. K., Chuecas, L., Riley, J. P. (1967). The component combined amino acids of some marine phytoplankton species. J. mar. biol. Ass. U.K. 47: 543-554

Chuecas, L., Riley, J. P. (1969). The component combined amino acids of some marine diatoms. J. mar. biol. Ass. U.K. 49: $117-120$

Crawford, C. C., Hobbie, J. E., Webb, K. L. (1974). The utilization of dissolved free amino acids by estuarine microorganisms. Ecology 55: 551-563

Davies, J. M., Payne, R. (1984). Supply of organic matter to the sediment in the northern North Sea during a spring phytoplankton bloom. Mar. Biol. 78: 315-324

Dawson, R., Duursma, E. K. (1981). State of the art. In: Duursma, E. K., Dawson, R. (ed.) Marine organic chemistry. Elsevier Oceanogr. Ser. 31, Amsterdam, p. 497-512

Degens, E. T. (1970). Molecular nature of nitrogenous compounds in sea water and recent marine sediments. In: Organic matter in natural waters. Inst. Mar. Sci. (Alaska), Occas. Publ. 1: 77-105

Dortch, Q., Clayton, J. R., Thoresen, S. S., Ahmed, S. I. (1984). Species differences in accumulation of nitrogen pools in phytoplankton. Mar. Biol. 81: 237-250

Eberlein, K., Kattner, G., Brockmann, U., Hammer, K. D. (1980). Nitrogen and phosphorus in different water layers at the central station during FLEX '76. 'Meteor' Forsch.Ergebn. A 22: 87-98

Eberlein, K., Brockmann, U. H., Hammer, K. D., Kattner, G., Laake, M. (1983). Total dissolved carbohydrates in an enclosure experiment with unialgal Skeletonema costatum culture. Mar. Ecol. Prog. Ser. 14: 45-58

Flynn, K. J., Syrett, P. J. (1985). Development of the ability to take up L-lysine by the diatom Phaeodactylum tricornutum. Mar. Biol. 89: 317-325

Flynn, K. J., Syrett, P. J. (1986a). Characteristics of the uptake system for L-lysine and L-arginine in Phaeodactylum tricornutum. Mar. Biol. 90: 151-158

Flynn, K. J., Syrett, P. J. (1986b). Utilization of L-lysine and L- arginine by the diatom Phaeodactylum tricornutum. Mar Biol. 90: 159-163

Fogg, G. E. (1977). Excretion of organic matter by phytoplankton. Limnol. Oceanogr. 22: 576-577

Fogg, G. E. (1983). The ecological significance of extracellular products of phytoplankton photosynthesis. Botanica mar. 26: 3-14

Gassmann, G., Gillbricht, M. (1982). Correlations between phytoplankton, organic detritus and carbon in North Sea waters during the Fladenground Experiment (FLEX 76). Helgoländer Meeresunters. 35: 253-262

Gieskes, W. W. C., Kraay, G. W. (1980). Primary productivity and phytoplankton pigment measurements in the northern North Sea during FLEX '76. 'Meteor' Forsch.-Ergebn. A $22: 105-112$

Gocke, K. (1970). Untersuchungen über Abgabe und Aufnahme von Aminosäuren und Polypeptiden durch Planktonorganismen. Arch. Hydrobiol. 67: 285-367

Gordon, W. G., Whittier, E. O. (1965). Proteins of milk. In Webb, B. H., Johnson, A. H. (ed.) Fundamentals of dairy chemistry. Avi Publishing Co., Westport, Conn., p. 54-90

Hammer, K. D., Brockmann, U. H. (1983). Rhythmic release of dissolved free amino acids from partly synchronized Thalassiosira rotula under nearly natural conditions. Mar. Biol. 74: 305-312

Hammer, K. D., Eberlein, K. (1981). Parallel experiments with Thalassiosira rotula in outdoor plastic tanks. Development. of dissolved free amino acids during an algae bloom. Mar. Chem. 10: 533-544

Hammer, K. D., Brockmann, U. H., Kattner, G., Eberlein, K., Weichart, G. (1979). Small scale nutrient variations around the Central Station from 24. 4. to 3. 5. 1976 during FLEX '76. Berichte aus dem Sonderforschungsbereich 94 (Univ. Hamburg) 15: 151-160

Hammer, K. D., Brockmann, U. H., Kattner, G. (1981). Release of dissolved free amino acids during a bloom of Thalassiosira rotula. Kieler Meeresforsch. (Sonderh.) 5: 101-109

Hammer, K. D., Eberlein, K., Kattner, G., Brockmann, U. H. (1983). Fluctuations of dissolved amino acids: A comparison between natural and enclosed phytoplankton populations. In: Sündermann, J., Lenz, W. (ed.) North Sea dynamics. Springer, Berlin, p. 559-572

Hecky, R. E., Mopper, K., Kilham, P., Degens, E. T. (1973). The amino acid and sugar composition of diatom cell walls Mar. Biol. 19: 323-331

Hentzschel, G. (1980). Wechselwirkungen bakteriolytischer und saprophytischer Bakterien aus der Nordsee. Mitt. Inst. allg. Bot., Hamburg 17: 113-124

Hollibaugh, J. T. (1980). Amino acid fluxes in marine plankton communities contained in Cepex bags. In: Freeland, H. J., Farmer, D. M., Levings, C. D. (ed.) Fjord oceanography. Plenum, New York, p. 439-445

Jeffries, H. P. (1969). Seasonal composition of temperature plankton communities: Free amino acids. Limnol. Oceanogr 14: 41-52

Kattner, G., Hammer, K. D., Eberlein, K., Brockmann, U. (1980). An attempt to determine fluxes of nitrogen and phosphorus in special time periods during FLEX 76. 'Meteor' Forsch.-Ergebn. A 22: 99-104

Krause, M., Trahms, J. (1983). Zooplankton dynamics during FLEX 76. In: Sündermann, J, Lenz, W (ed.) North Sea dynamics. Springer, Berlin, p. 632-661

Laanbroek, H. J., Verplanke, J. C., de Visscher, P. R. M., de Vuyst, R. (1985). Distribution of phyto-and bacterioplankton growth and biomass parameters, dissolved inorganic nutrients and free amino acids during a spring bloom in 
the Oosterschelde basin, The Netherlands. Mar. Ecol. Prog. Ser. 25: 1-11

Liebezeit, G., Bölter, M., Brown, J. F., Dawson, R. (1980). Dissolved free amino acids and carbohydrates at pycnocline boundaries in the Saragossa Sea and related microbial activity. Oceanologica Acta 3: 357-362

Lu, M., Stephens, G. C. (1984). Demonstration of net influx of free amino acids in Phaeodactylum tricornutum using high performance liquid chromatography. J. Phycol. 20: 584-589

Lu, M., Stephens, G. C. (1985). Uptake of free amino acids by the diatom, Melosira mediocris. Hydrobiologia 128: 187-191

Mackinnon, M. D. (1981). The measurement of organic carbon in sea water. In: Duursma, E. K., Dawson. R. (ed.) Marine organic chemistry. Elsevier Oceanogr. Ser. 31, Amsterdam, p. 415-443

Macko, S. A., Green, E. J. (1982). An investigation of the dissolved free amino acids and their relation to phytoplankton cell density in the Damariscotta river estuary, Maine. Estuary 5: 68-73

Mague, T. H., Friberg, E., Hughes, D. J., Morris, I. (1980). Extracellular release of carbon by marine phytoplankton, a physical approach. Limnol. Oceanogr. 25: 262--279

Mopper, K., Lindroth, P. (1982). Diel and depth variations in dissolved free amino acids and ammonium in the Baltic Sea determined by shipboard HPLC analysis. Limnol. Oceanogr. 27: 336--347

Morris, J. (1981). Photosynthetic products, physiological state, and phytoplankton growth. In: Platt, T. (ed.) Physiological bases of phytoplankton ecology. Can. Bull. Fish. Aquat. Sci. 210: 83-102

North, B. B., Stephens, G. C. (1972). Amino acid transport in Nitzschia ovalis Arnott. J. Phycol. 8: 64-68

Paul, J. H. (1983). Uptake of organic nitrogen. In: Carpenter, E. J., Capone, D. G. (ed.) Nitrogen in the marine environment. Academic Press, New York, p. 275-308

Poulet, S. A., Martin-Jézéquel, V. (1983). Relationships between dissolved free amino acids, chemical composition and growth of the marine diatom Chaetoceros debilis. Mar. Biol. 77: 93-100

Poulet, S. A., Martin-Jézéquel, V., Head, R. N. (1984). Distribution of dissolved free amino acids in the Ushant front region. Mar. Ecol. Prog. Ser. 18: 49-55

Raymont, J. E. G., Morris, R. J., Ferguson, G. F., Raymont, J. K. B. (1975). Variation in the amino-acid composition of lipid-free residues of marine animals from the northeast Atlantic. J. exp. Mar. Biol. Ecol. 17: 261-267

Sharp, J. H. (1977). Excretion of organic matter by marine phytoplankton: do healthy cells do it? Limnol. Oceanogr. 22: $381-399$

Siezen, R. J., Mague, T. H. (1978). Amino acids in suspended particulate matter from oceanic and coastal waters of the Pacific. Mar. Chem. 6: 215-231

Smith, W. O., Jr, Barker, R. T., Huntsman, S. A. (1977). Primary production off the coast of Northwest Africa: Excretion of dissolved organic matter and its heterotrophic uptake. Deep Sea Res. 24: 35-47

Soetje, K. C., Huber, K. (1980). A compilation of data on the thermal stratification at the Central Station in the northern North Sea during FLEX '76. 'Meteor' Forsch.-Ergebn. A 22: 69-77

Wangersky, P. J. (1978). Production of dissolved organic matter. In: Kinne, O. (ed.) Marine ecology, Vol. IV, Dynamics. Wiley, Chichester, p. 115-220

Wheeler, P. A. (1983). Phytoplankton nitrogen metabolism. In: Carpenter, E. J., Capone, D. G. (ed.) Nitrogen in the marine environment. Academic Press, New York, p. 309-346

Wheeler, P. A., North, B. B., Stephens, G. C. (1974). Amino acid uptake by marine phytoplankters. Limnol. Oceanogr. 19: 249-259

Wheeler, P., North, B., Littler, M., Stephens, G. (1977). Uptake of glycine by natural phytoplankton communities. Limnol. Oceanogr. 22: 900-910

Williams, P. J. LeB. (1975). Biological and chemical aspects of dissolved organic material in the sea water. In: Riley, J. P., Skirrow, G. (ed.) Chemical oceanography, 2nd ed. Academic Press, London, p. 301-363

Williams, P. J. LeB. (1981). Incorporation of microheterotrophic processes into classical paradigm of the planktonic food web. Kieler Meeresforsch. (Sonderh.) 5: 1-28

Williams, P. J. LeB., Yentsch, C. S. (1976). An examination of photosynthetic production, excretion of photosynthetic products, and heterotrophic utilisation of organic compounds with reference to result from a coastal subtropical sea. Mar. Biol. 35: 31-40

Williams, R., Poulet, S. A. (1986). Relationship between the zooplankton, phytoplankton, particulate matter and dissolved free amino acids in the Celtic Sea. Mar. Biol. 90: $279-284$ 